\title{
To ranch or not to ranch: Home on the urban range?
}

\author{
ROBIN H. LIFFMANN, LYNN HUNTSINGER, AND LARRY C. FORERO
}

Authors are graduate student researcher and associate professor, Department of Environmental Science, Policy, and Management, University of California, Berkeley, Calif. 94720; and University of California Cooperative Extension Livestock Farm Advisor, Shasta County.

Abstract

California ranchers in urban Alameda and Contra Costa Counties, and in rural Tehama County, were surveyed to examine effects of increasing development, land use change, and attrition of the ranching community on their commitment to ranching, and to assess land conservation program acceptability. Questions were about practices, reasons for ranching, and what influences ranching's future. Ranchers share much in common. Most enjoy ranching, "feeling close to the earth," living in a "good place for family life," and the camaraderie in the ranching community. They regularly carry out range improvements. Most believe that society is becoming "hostile to ranching." A dislike for outsider intervention and land use control prevails. Urban ranchers cared significantly less about the fate of their ranch if sold, and feared local land use planning much more. Rural ranchers overwhelmingly wanted their ranch to remain a productive ranch even if sold. No new ranchers appeared in the urban sample for the last 10 years. As urbanization proceeds, we suggest that a point is reached where ranchers recognize the social, ecological, and economic landscape as urban and see it as no longer suitable for ranching. Expecting to sell for development, and/or expecting zoning to change to allow it, becomes the rational view. Land conservation efforts, including relatively acceptable though as yet not widespread conservation easement programs, should begin before that happens.

Key Words: land use change, land trusts, rangeland conversion, ranch values

Ranchers own most of California's highly productive low elevation annual rangelands, an estimated 8.1 million ha of oak woodland and annual grassland (Ewing et al. 1988). Studies of oak woodlands statewide have shown they are two-thirds owned by livestock producers with holdings larger than 8 ha, and about three-fourths grazed (Huntsinger et al. 1997, Holzman 1993, Bolsinger 1988). Annual rangelands produce an average of 700 $\mathrm{kg} / \mathrm{ha}$ of biomass each year under conservative stocking, and provide watershed, wildlife habitat, and open space. Although such benefits are now earning broad acknowledgment, rangelands are at growing risk of residential development, or conversion to high

Research was funded in part by the Agricultural Experiment Station. The authors wish to thank Rebecca Richards and Sheila Barry for their help in developing the questionnaire for the study, and Paul F. Starrs and our anonymous reviewers for their thoughtful comments and suggestions.

Muchos gracias to Antonio Ceballos and Pablo Estrellas of the University of Salamanca for translating the abstract into Spanish.

Manuscript accepted 10 Nov. 1999.

\section{Resumen}

Rancheros californianos fueron estudiados, en los condado urbanos de Alameda y Contra Costa y en el rural de Tehama, para conocer los efectos de la urbanización, y de los cambios en el uso del suelo, en relación con el temor de los rancheros a que ello suponga una disminución o pérdida de la comunidad ranchera. También se analizaron sus opiniones acerca del contenido de diversos programas sobre la conservación de los usos posibles del suelo y la tenencia del mismo. El contenido de las preguntas versó sobre las prácticas de los rancheros, las razones que tenían para continuar con su modo de vida y qué aspectos, según ellos, pueden influir en el futuro de su existencia. El sondeo refleja bastante unaimidad en las opiniones de los rancheros. En la mayoría de los casos les gusta ranchear, "sentire que están pisando la tierra", "vivir en en buen lugar para la vida familiar" y disfrutar del compañerismo dentro de la comunidad. Trabajan juntos en el desarrollo de proyectos para la mejora del campo y de los terrenos de pastoreo. Muchos opinan que en la sociedad, en general, existe cierta aversión hacia los rancheros y su modo de vida. Entre los rancheros predomina un sentimiento de decepción hacia los forasteros y con los intentos de intervención exterior para controlar los usos del terreno. Los rancheros urbanos no muestran tanta preocupación sobre las consecuencias de las ventas de sus ranchos, sin embargo temen más que el gobierno les limite los usos de la tierra o la oportunidad de vender sus propiedads. Los rancheros rurales, de manera contundente, desean que sus ranchos continúen siendo productivos, aunque sean vendidos. Ningún ranchero urbano nuevo, perteneciente a los últimos diez años, aparece en el grupo encuestado. Con el proceso de urbanización avanzando, nosotros sugerimos que se llegue a un punto donde los rancheros reconozcan el entorno social ecológico y económico de su rancho dentro de un paisaje urbano y no lo vean como la continuación del rancho. La expectativa de vender su propiedad para el desarrollo, y/o esperar un cambio en las leyes que permita tal desarrollo, es un punto de vista lógico. Los esfuerzos encaminados a la conservación de la tierra, incluyendo programas que aunque no muy extendidos todavía sean aceptables para muchos rancheros, deberían ser puestos en marcha antes de que el proceso de ventas de parcelas o urbanización del campo ocurra.

value products such as wine grapes. Urban out-growth is becoming more common throughout the West (Wright 1993a).

This paper compares results of a survey of ranchers in a highly urban area of California and a mostly rural, but growing, area. The goal was to examine how increased expectations of development and the attrition of the ranching community that comes with a more urban landscape affects a rancher's commitment to ranching, and to help assess what sorts of land conservation programs 
are most acceptable. Ranchers were asked about their management practices, their reasons for ranching, and what they think is likely to influence the future of ranching.

\section{Rangeland Conversion Patterns}

Drawn by open space, affordable housing, and rural lifestyles, a growing population is stimulating conversion of California rangelands to new uses, transforming the landscape through development. A study of Sierran foothill oak woodlands and grasslands found ranchers a shrinking proportion of ownerships. Estate taxes, conflicts between multiple heirs, and lucrative purchase offers encourage ranchers to sell land to developers, and much land is being purchased and held for development by corporate and individual speculators (Johnson 1998). In his economic case study in the Sierra foothills, Hargrave (1993) found ranching unprofitable when the opportunity costs of investment were considered-the only economic justification for ranching was to hold land for increased real estate value. Smethurst (1997) concluded that the Sierra foothills were "being transformed to an absenteeowned landscape, where natural resources such as water, timberland, and recreational assets are owned by those living outside the region. Residential development has increased, while ranching, farming, and hardwood rangeland have declined."

In 1965, in response to loss of agricultural land, the California Land Conservation Act was passed, commonly referred to as the Williamson Act. Participant landowners, including more than half of California's rangeland owners (Huntsinger et al. 1997, McClaran et al. 1985), enroll in a 10-year rolling land conservation contract with their county in exchange for tax relief. However, McClaran et al. (1985) found this effective only in areas where development pressure was not yet high.

Accessibility and distance from a desired destination, such as a city center or airport, are commonly held to explain patterns of urban growth and development (Furuseth and Pierce 1982). Land conversion pressure does appear greatest on the urban fringe (Hart 1991a, McClaran et al. 1985), but the decision process for land conversion includes political, institutional and behavioral factors in addition to proximity (Furuseth and Pierce 1982). The public generally assumes that governmentinstituted land use regulations at local and regional levels control rangeland conversion. Researchers have recently pointed out that urban growth limits and sprawl controls are a neglected key to rural con- servation in the United States (Alterman 1997, Gale 1992). However decisions of private landowners in fact play a pivotal role in determining future land use (Platt 1991, Johnston and Bryant 1987). Principal factors influencing the sequence and form of development have been summarized by Kaiser and Weiss (1970) as: (1) contextual factors-socio-economic characteristics, including land policies dealing with municipal infrastructure and services and land use regulations; (2) property factors-such as location and physical characteristics of the property; and (3) decision agent factors - the players in the development process and their goals, expectations, and motivations. Obviously, these factors are hardly independent, but this research focuses on the third factor, the decision agent or landowner. According to Furuseth and Pierce (1982), "if one wishes to influence successfully the location and pattern of land conversion, then one must understand the principal decision-makers and the linkages that exist among them."

\section{Rancher Decisionmaking}

The importance of rancher decisionmaking has been noted by a number of researchers (Hart 1991a, 1991b, 1976; Berry and Plaut 1978), and is best summed by Johnson (1998): "a single ranch-owner's decision may spell the fate of many thousands of acres. Landowner decisions affect more than their own property, as nearby properties are also influenced through the fragmentation of land use, weakening of the agricultural infrastructure, changing land values, and the creation of new growth nodes in previously undeveloped areas."

Numerous studies note that social factors, values, and attitudes, and not just profits strongly affect the decisions of range livestock producers. In a 1995 survey, the majority of California oak woodland ranchers reported that "living near natural beauty" was an important reason to ranch (Huntsinger et al. 1997). Similar results have been found elsewhere in the western U.S. (Smith and Martin 1972). "Ranch fundamentalism," an idealization of the independent ranching lifestyle, and the benefits of ranching to family life, have been described by economists and others as motivating decisions to keep ranching despite the low profits characteristic of the industry at the producer level (Bartlett et al. 1989, Smith and Martin 1972, Martin and Jefferies 1966). Smith and Martin (1972) reported that Arizona ranchers resisted selling ranches at market prices far exceeding their value as livestock operations for reasons that included "love of the land," and "love of rural values." Hargrave (1993) found that Sierran ranchers persist despite economic hardship and development pressure because they enjoy the tradition and way of life, and want their children to ranch if they so choose. Based on similar findings, ranches have been described as units of consumption rather than production (Grigsby 1980, 1976).

Comparison of urban and rural ranchers allows identification of "transitional effects" that influence rancher decisions, such as rising land speculation, an increase in conflicts with community and neighbors, and loss of the "critical mass" of ranchers necessary to maintain agricultural support services and markets (Huntsinger and Hopkinson 1996, Hart 1991a, 1991b, Heimlich and Anderson 1987, Lisansky and Clark 1987, Berry and Plaut 1978). Rising land speculation can create an environment that encourages a feeling of impermanence; landowners expect to sell out for non-agricultural uses (Berry and Plaut 1978). The term "impermanence syndrome" describes the reduced land and property management, and accompanying lack of investment in farming or ranching that may result when returns anticipated from development far outweigh the returns possible from agriculture (Heimlich and Anderson 1987). If sometimes unrealistic, price expectations can reduce landowner participation in conservation efforts such as the Williamson Act (McClaran et al. 1985). Some researchers have argued that reduced dependence on income from agricultural production will also contribute to a lack of investment and management activity by the landowner (Fortmann and Huntsinger 1989).

Conflicts over odors, noise, stray livestock, human trespass, vandalism, and pet predation may result in formal litigation or restriction of agricultural activities through ordinances or zoning (Lisansky and Clark 1987, Conklin and Lesher 1977). Ranchers, used to resolving disputes through peer relations (Ellickson 1991), face an influx of newcomers with different, often litigious, ideas about recourse, multiplying misunderstanding and cementing conflict. Mutual cooperation or reciprocity and resolution of conflicts through peer relations, are common and successful traits among pastoralists world-wide (Roe et al. 1998, Sandford 1983). Ranching has traditionally relied on the cooperation and participation of neighbors in rounding up herds, brandings, and 
other activities requiring many people for a short period of time (Starrs 1998). Helping neighbors who help you has social and practical benefits that cement a cohesive ranching community. The transition from a rural to urban landscape fractures the social, economic, and ecological structure of the ranching community, contributing to rancher decisions to sell land for development.

\section{Rangeland Conservation Options}

In popular "environmentalist" writings, ranching is often constructed as an exploitative, environmentally destructive activity motivated by greedy and neglectful livestock operators (Jacobs 1991, Wuerthner 1990). In recent years, ranching has been reconceived by elements in the conservation movement as an apt way of conserving open space and wildlife habitat, particularly through the establishment of land trusts and conservation easements (Huntsinger and Hopkinson 1996, Wright 1993a, 1993b, 1994). Diverse groups including the California Cattlemen's Association, the Nature Conservancy, the National Park Service, the Bureau of Land Management, and a variety of local organizations have supported such programs. Determining the best strategies and the acceptability of various programs requires knowledge of rancher values and motives.

Land use planning and zoning may reduce rangeland conversion, but are subject to fluid political and economic objectives. They have proven useful for temporarily slowing development until more permanent conservation strategies can be employed, such as conservation easements (Hart 1991b). Property rights include a variety of rights, such as mineral rights, grazing rights, rights to develop, and rights to sell, each of which can be sold or contracted separately (Raymond 1997, Huntsinger and Hopkinson 1996, Daniels 1991). Property owners can sell or donate the right to develop land in perpetuity as part of creating a conservation easement. Easement sales can compensate for loss of land value or buy out heirs; donation or sale of easements can reduce taxes. Other rights, including the right to sell, are retained as defined in the easement agreement, and the land remains private and in production. Voluntary, incentive-based programs such as conservation easements and land trusts depend on willing landowner cooperation, and according to Wright (1994), work best in areas where people are committed to conserving a way of life. But in regions of rapid growth and rising land values, does this commitment wane?

\section{Methods}

Range livestock producers in 2 areas, Tehama County, and Alameda/Contra Costa Counties, were surveyed by mail. Samples were randomly selected from a compilation of U.C. Extension's Farm Advisor list, Natural Resource Conservation Service (NRCS) list, and an emergency feed program list. The questionnaire was edited and pretested working with natural resource management professionals, and ranchers not selected for sampling, within and outside the study areas.

\section{Study Areas}

Tehama County and the combined Alameda and Contra Costa Counties (ACC) are similar in resources, with livestock forage mostly of Mediterranean-type annual grasses. Both study areas have strong agricultural components in their county General Plans and participate in the Williamson Act.

Tehama County is 764,000 ha in the upper reaches of California's Sacramento Valley, about $200 \mathrm{~km}$ north and inland of the San Francisco Bay counties of Alameda and Contra Costa (Fig. 1)(Table 1). Hilly chaparral, oak woodland, and annual grass rangelands make up most of Tehama, bordered on the west by the coast range, and on the east by Sierra Nevadan lava rock ranges and coniferous forests. A predominately agricultural county, croplands and much of the irrigated grazing land follow the Sacramento River flowing north to south through the valley floor. The urban areas of Red Bluff and Corning contain around $37 \%$ of the county's 52,000 people, and lie within the Interstate 5 (I-5) corridor paralleling the river. Average population density for the county was .07 per ha in 1994 (Table 1). Tehama County planners consider agriculture of prime importance, though industrial, commercial and residential development is encouraged along the I-5 corridor on land unsuitable for crops. Ranching is considered by county planners to be flexible and suitable for marginal lands (Tehama

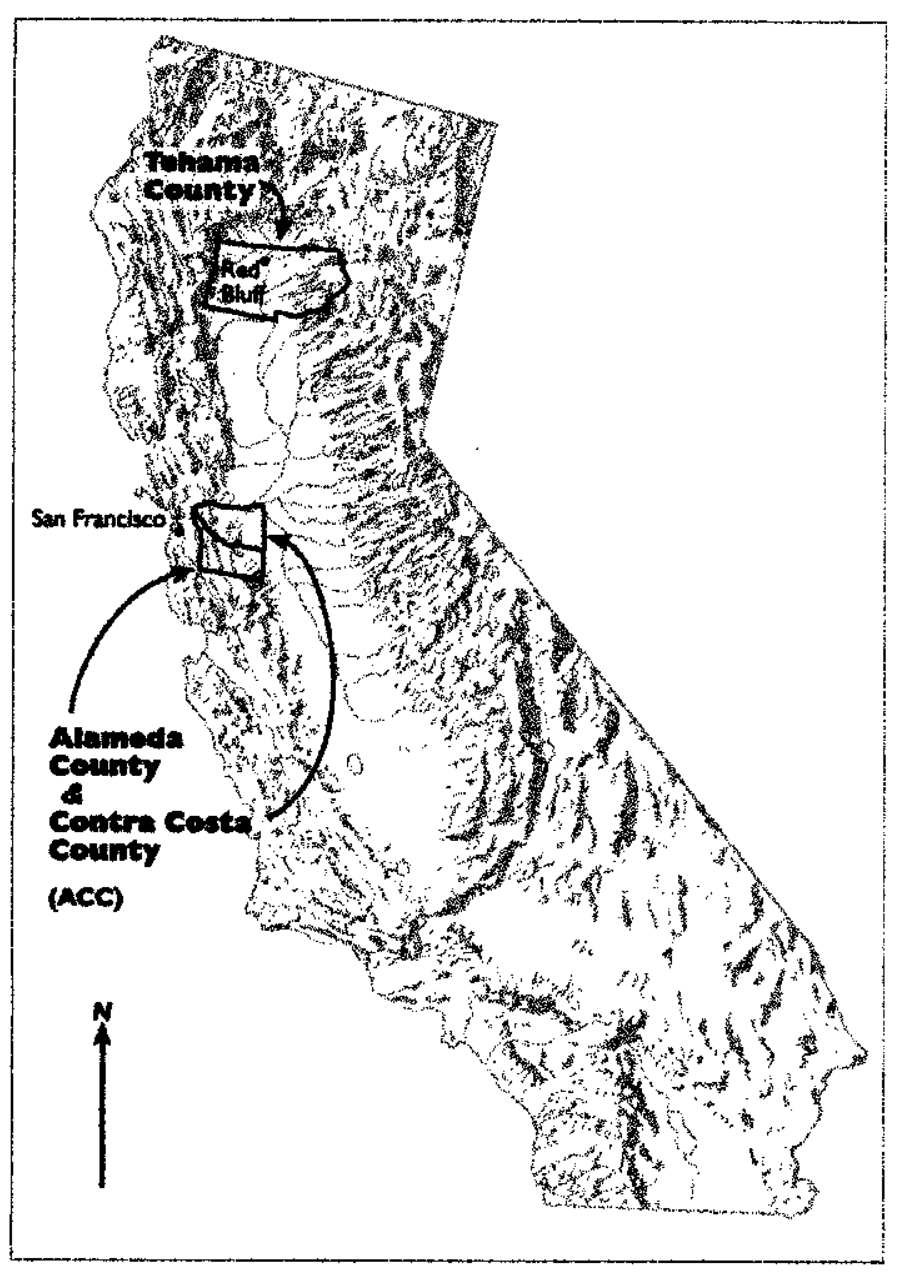

Fig. 1. Tehama, Alameda, and Contra Costa Counties, Calif. 
Table 1. Characteristics of Tehama and Alameda-Contra Costa Counties, California.

\begin{tabular}{lrrrr}
\hline \hline & & $\begin{array}{c}\text { Percent } \\
\text { Tehama } \\
\text { study area }\end{array}$ & $\begin{array}{c}\text { Percent } \\
\text { ACC } \\
\text { Contra Costa }\end{array}$ & $\begin{array}{c}\text { Alameda- } \\
\text { study area }\end{array}$ \\
\hline Total land area (ha) & Tehama & 100.0 & 378,000 & 100.0 \\
BLM (ha) & 764,000 & 2.7 & 800 & .2 \\
USFS (ha) & 21,000 & 20.6 & 0 & 0.0 \\
Other public (ha) & 158,000 & 3.01 & 31,500 & 8.3 \\
All public (ha) & 23,000 & 26.2 & 32,300 & 8.5 \\
1993 irrigated range (ha) & 202,000 & 1.2 & 1,939 & .5 \\
1993 non-irrigated range (ha) & 9,106 & 49.3 & 155,587 & 41.2 \\
Population in 1994 & 376,371 & & $2,148,157$ & $5.70 / \mathrm{ha}$ \\
Population density & 51,903 & & $\$ 125,533,750$ & $\$ 11,478,000.00$ \\
Value ag products in 1993 & $0.07 / \mathrm{ha}$ & & $\$ 220.00$ & $\$ 37.00$ \\
Value beef cattle/calves in 1993 & $\$ 100,365,200$ & & &
\end{tabular}

Sources: Contra Costa Department of Agriculture 1993, Tehama County Department of Agriculture 1993, U.S. Dept. of Commerce 1992 and 1994, Ewing et al. 1988.

County Planning Dept. 1990, G. Robson, Planning Director, Tehama Co., pers. comm. 1995). Between 1984 and 1994, urban acreage increased by 522 ha in Tehama (FMMP 1996).

Alameda and Contra Costa Counties are adjacent and stretch from the eastern shore of San Francisco Bay to the western edge of the Sacramento Valley. Their combined 377,634 ha (Table 1) incorporates densely populated, urbanized development and less populated agricultural area, where a marine influence and mild winters support some of the most productive annual grass rangeland in the State (Forero et al. 1992). With about half the rangeland of Tehama, Alameda and Contra Costa produce about the same value of beef cattle and calves (Table 1). The average population density of 5.7 per ha (Table 1) is spatially concentrated in the western and north central sections of the counties (Landis et al. 1993). But the coast range oak woodlands and grasslands that comprise the eastern agricultural area are undergoing intense development pressures and skyrocketing land values (Forero et al. 1992). The General Plan of Alameda County has an Urban Growth Boundary, and Contra Costa County has a designated Urban Limit Line (ULL), that delimit areas suitable for urban development versus areas suitable for long-term protection of natural resources, agriculture, and open space (ACPD 1994, CCCCDD 1991). Between 1984 and 1994, urban acreage increased by 10,222 ha in Alameda and Contra Costa counties (FMMP 1996).

\section{Rancher Survey}

In the winter of 1993/94, ranchers were surveyed by mail using the questionnaire style and 4-wave mailing technique

\section{Results}

Respondents in the 2 study areas were similar demographically: the majority were owner-operators, male, of mean age 50 , with some college education, and third or more generation rancher (Table 2). Most had a family or individual cow-calf operation, sometimes in combination with stocker production. Only a few ranchers had only sheep or a combination of cattle and sheep, with significantly less sheep ranchers in Alameda-Contra Costa (ACC) than in Tehama (Table 2).

There were more Tehama than ACC ranchers in the lower income brackets, and ACC ranchers had more often obtained college degrees (Table 2). American per capita personal income figures (1993 dollars) show a mean of $\$ 25,433$ for $\mathrm{ACC}$ and $\$ 14,276$ for Tehama, a $56 \%$ difference between the study sites (Calif. Dept. of Finance 1996). Significantly more Tehama ranchers earned $75 \%$ or more of their income from ranching, while significantly more ACC ranchers earned less than $25 \%$ of their income from ranching (Table 2).

Alameda and Contra Costa County ranchers had owned their land significantly longer. More than two-thirds of all respondents had owned their land for 25 or more years, but close to half of ACC families had owned their land for at least 50 years, and more than a quarter for 100 years plus. None of the ACC sample had owned their land for less than 10 years (Table 2). Two-thirds of all respondents had land enrolled in the Williamson Act, and $4 \%$ had land in a conservation easement. In ACC, ranches were in significantly closer proximity to current or planned development (Table 2).

Overwhelmingly, ranchers found other ranchers, and University of California Cooperative Extension, to be useful information sources. Other common sources were pharmaceutical companies and veterinarians, the local Farm Bureau, and the National Cattleman's Association (Table 2).

Most rangeland grazing in both sites took place on private rather than public land. Tehama ranchers grazed larger properties than ACC ranchers. About a third of Tehama ranchers had livestock graze part of the year outside the county, compared to less than a quarter of ACC ranchers (Table 2). areas, while Student's t-test was used to compare grouped continuous variables such as respondent age or how many years the ranch was owned (Spicer 1972). Differences of P $<.1$ are discussed as significant.

\section{Goals, Practices, and Management}

Improving livestock quality and increasing production, as well as improving the quality and quantity of forage, and improving soil stability and wildlife habi- 
Table 2. Demographics and ranch ownership in Tehama and Alameda-Contra Costa Counties, California, 1994.

\begin{tabular}{|c|c|c|c|}
\hline & $\begin{array}{l}\text { Tehama } \\
\text { Ranchers } \\
(\mathrm{n}=132)^{1}\end{array}$ & $\begin{array}{c}\text { Alameda/Contra } \\
\text { Costa Ranchers } \\
(\mathrm{n}=113)\end{array}$ & $\mathrm{P}\left(\mathrm{X}^{2}\right)$ \\
\hline Some college or higher & 75 & 61 & .02 \\
\hline 3 rd + generation rancher & 60 & 60 & .99 \\
\hline \multicolumn{4}{|l|}{ Gross income: } \\
\hline less than $\$ 25,000$ & 18 & 6 & .01 \\
\hline $25,000-74,999$ & 61 & 56 & .54 \\
\hline more than $\$ 75,000$ & 21 & 38 & .01 \\
\hline \multicolumn{4}{|l|}{ Percent income from ranch: } \\
\hline $75 \%-100 \%$ & 33 & 23 & .07 \\
\hline $25 \%$ or less & 30 & 52 & .00 \\
\hline Mean years owned land: & 39 & 63 & .00 \\
\hline Owned land $<10$ yrs & 13 & 0 & .00 \\
\hline \multicolumn{4}{|l|}{ Type of ranch operation: } \\
\hline cow-calf only & 45 & 35 & .10 \\
\hline cow-calf and stocker & 21 & 25 & .46 \\
\hline sheep only & 11 & 5 & .08 \\
\hline sheep and cattle & 11 & 4 & .04 \\
\hline Raises food crops & 41 & 32 & .20 \\
\hline Raises horses & 28 & 39 & .08 \\
\hline Goes hunting or fishing on ranch & 52 & 29 & .00 \\
\hline Uses own irrigated pasture or meadow & 84 & 35 & .00 \\
\hline Grazes in more than one county & 32 & 18 & .02 \\
\hline Grazes some public land & 30 & 35 & .40 \\
\hline Enrolled in Williamson Act & 67 & 69 & .71 \\
\hline Land in conservation easement & 4 & 4 & .92 \\
\hline \multicolumn{3}{|l|}{ Grazes more than 809 ha of } & .02 \\
\hline Grazes $1-20$ ha of own property & 25 & 30 & .40 \\
\hline \multicolumn{4}{|l|}{ Distance from development } \\
\hline ranch is part of one & 0 & 4 & .00 \\
\hline $8 \mathrm{~km}$ or less & 58 & 81 & .00 \\
\hline \multicolumn{4}{|l|}{ UC Cooperative Extension } \\
\hline is a useful source of information & 92 & 81 & .02 \\
\hline \multirow{2}{*}{$\begin{array}{l}\text { Other ranchers are a good source } \\
\text { of information }\end{array}$} & & & \\
\hline & 97 & 95 & .51 \\
\hline
\end{tabular}

Table 3. Ranching goals and practices, Tehama and Alameda-Contra Costa Counties, California, 1994.

\begin{tabular}{lccc}
\hline \hline $\begin{array}{l}\text { The following are important goals } \\
\text { for my ranch: }\end{array}$ & $\begin{array}{c}\text { Tehama } \\
\text { Ranchers } \\
(\mathrm{n}=132)^{1}\end{array}$ & $\begin{array}{c}\text { Alameda/Contra } \\
\text { Costa Ranchers } \\
(\mathrm{n}=113)\end{array}$ & $\mathrm{P}\left(\mathrm{X}^{2}\right)$ \\
\hline & $--------(\%)----------$ & \\
Improving wildlife habitat & 78 & 69 & .12 \\
Increasing forage & 95 & 97 & .66 \\
Improving soil stability & 94 & 90 & .23 \\
Increasing livestock production & 89 & 91 & .44 \\
Protect scenic values & 78 & 67 & .05 \\
Diversify operation & 41 & 37 & .52 \\
Reduce need for pesticides & & & \\
and herbicides & 79 & 68 & .05 \\
Improve livestock quality & 99 & 98 & .91 \\
\hline
\end{tabular}

Have carried out the following

practices in last 5 years:

Prescribed or controlled burn

Herbicides

Chaining or thinning

Browsing by goats or others

Controlled grazing

Deferred or rest rotation

Continuous year-round grazing

Seeding rangeland

Fencing riparian areas

Commercial fertilizers

Manure application

Mulching with ungrazed forage

Electric fencing

Developed springs

Put in water tanks or troughs

Laid water pipe

Stabilized streambanks

Overall satisfied with

range condition

Used volunteer labor

by neighbors

$\mathrm{n}$ varies slightly by question. (1) (1) .05 . 
Table 4. Management issues, Tehama and Alameda-Contra Costa Counties, California, 1994.

\begin{tabular}{|c|c|c|c|}
\hline $\begin{array}{l}\text { What they would do if found someone else's } \\
\text { livestock on property: }\end{array}$ & $\begin{array}{l}\text { Tehama } \\
\text { Ranchers } \\
(\mathrm{n}=132)^{1}\end{array}$ & $\begin{array}{c}\text { Alameda/Contra } \\
\text { Costa Ranchers } \\
(n=113)\end{array}$ & $\mathrm{P}\left(\mathrm{X}^{2}\right)$ \\
\hline \multicolumn{4}{|c|}{---------(\%)------------- } \\
\hline Shoot the animals & 2 & 0 & \\
\hline Call the Brand Inspector & 2 & 0 & \\
\hline Round them up and return them & 39 & 39 & \\
\hline Call or talk to the owner by phone & 56 & 53 & .58 \\
\hline Report them to the sheriff & 2 & 0 & \\
\hline Do nothing & 0 & 0 & \\
\hline
\end{tabular}

Found people trespassing or stray cattle on their

land in last 2 years:

People trespassing:

2 - 10 times

more than 10 times

Stray cattle:

2- 10 times

more than 10 times

Agrees with the following about grazing on public lands:

Is important for U.S. sheep and cattle production

Is degrading the land

Low fees penalize ranchers on private lands

Is important to local economies

Private lands are better managed

n varies slightly by question.

that "feeling close to the earth" and having "a good place to raise a family" are important reasons to continue ranching. But Tehama ranchers placed significantly greater importance on working and visiting with friends and neighbors as a motivation to ranch (Table 5).

Commonly held reasons to quit ranching included 'being over-regulated,' ranked important by over $80 \%$ of all respondents, 'society's hostility towards ranching,' also denoted important by two-thirds of ACC and Tehama ranchers, and leaving to 'improve current investment returns,' indicated important by over half of all respondents. However, significantly more Tehama respondents considered 'the next generation not wanting to ranch' an important reason to stop ranching, and said that one reason they keep ranching is because of the 'chance to work and visit with friends, neighbors and/or relatives.' Significantly more Tehama respondents also agreed that a reason to keep ranching is that it is hard to find another job, and that finding another job is a good reason to quit (Table 5).

Reported by most ranchers as serious or extreme "threats to ranching" in general were state or federal wilderness designations, statewide or regional planning, the Endangered Species Act, animal rights, closure of open range, efforts to increase recreational access to public lands, "environmentalism," trespassing, efforts to raise grazing fees on public lands, and urbanization of California. Overwhelmingly more your ranch, how desirable, if at all, would it be to you to see the following happen as a result of your choice of buyer?" More than three-quarters of Tehama ranchers wanted the ranch to remain private and used for livestock grazing, while over a third of ACC respondents indicated that it didn't matter to them (Table 7). Half of ACC respondents indicated that it is desirable to have the ranch developed for residential use or that it makes no difference, whereas more than two-thirds of Tehama respondents declared this an undesirable outcome. Finally, a quarter of ACC respondents were indifferent to whether their ranch is sold to a public owner or to a non-profit organization, while most Tehama respondents found these 2 options undesirable (Table 7).

\section{Discussion and Conclusions}

Ranchers in predominately agricultural Tehama County and in rapidly developing Alameda and Contra Costa Counties were more alike than dissimilar in attributes, values and motives, land management practices, and attitudes toward land use change. However, significant differences between the 2 study sites illustrate urbanization's effects on ranching.

Ranches in both sites were mostly family-oriented, privately-owned livestock operations run by third or greater generation ranchers with at least some college education. Although gender roles are out-

\section{Attitudes Toward Land Use Change}

Significant differences between study sites were found in the response to the question, "If you should decide to sell

\section{Table 5. Rancher motivations, Tehama and Alameda-Contra Costa Counties, California, 1994.}

\begin{tabular}{|c|c|c|c|}
\hline $\begin{array}{l}\text { Agrees the following is a good reason to } \\
\text { keep ranching: }\end{array}$ & $\begin{array}{l}\text { Tehama } \\
\text { Ranchers } \\
(\mathrm{n}=132)^{1}\end{array}$ & $\begin{array}{c}\text { Alameda/Contra } \\
\text { Costa Ranchers } \\
(n=113)\end{array}$ & $\mathrm{P}\left(\mathrm{X}^{2}\right)$ \\
\hline & \multicolumn{2}{|c|}{----------(\%)------------- } & \\
\hline Selling the ranch is hard & 17 & 39 & .00 \\
\hline Like working with friends, relatives & 66 & 47 & .00 \\
\hline Getting another job is hard & 25 & 12 & .00 \\
\hline It allows me to feel close to the earth & 92 & 90 & .41 \\
\hline A ranch is a good place for family life & 98 & 94 & .50 \\
\hline Ranching is profitable & 62 & 57 & .46 \\
\hline I want my children to ranch & 54 & 46 & .24 \\
\hline Ranching is what I have always done & 55 & 51 & .51 \\
\hline Keeping the ranch is a good investment & 47 & 53 & .36 \\
\hline \multicolumn{4}{|c|}{ Agrees the following is a good reason to quit ranching: } \\
\hline To find another job & 34 & 19 & .02 \\
\hline My kids don't want to ranch & 39 & 26 & .04 \\
\hline Over-regulation & 91 & 83 & .07 \\
\hline Society is hostile to ranching & 73 & 65 & .18 \\
\hline To improve investment returns & 58 & 50 & .27 \\
\hline To sell or lease ranch in a better market & 35 & 40 & .50 \\
\hline I don't want my children to ranch & 19 & 20 & .90 \\
\hline My kids have moved away & 20 & 18 & .74 \\
\hline To move closer to services & 18 & 16 & .55 \\
\hline My friends have moved away & 11 & 14 & .56 \\
\hline
\end{tabular}


Table 6. Threats to ranching, Tehama and Alameda-Contra Costa Counties, California, 1994.

\begin{tabular}{lccc}
\hline \hline & $\begin{array}{c}\text { Tehama } \\
\text { Ranchers } \\
(\mathrm{n}=132)^{1}\end{array}$ & $\begin{array}{c}\text { Alameda/Contra } \\
\text { Ranchers } \\
(\mathrm{n}=113)\end{array}$ & $\mathrm{P}\left(\mathrm{X}^{2}\right)$ \\
\hline Animal rights & $-------(\%)--------$ & .42 \\
State \& federal water quality standards & 86 & 82 & .00 \\
Endangered Species Act & 85 & 63 & .37 \\
Statewide/Regional Planning & 86 & 81 & .58 \\
Local land use planning & 79 & 82 & .00 \\
Urbanization of California & 54 & 82 & .75 \\
Raising grazing fees on public lands & 87 & 77 & .18 \\
Vandalism and theft & 63 & 71 & .00 \\
Trespassing & 76 & 59 & .04 \\
Environmentalism & 78 & 66 & .89 \\
State or federal wilderness designations & 87 & 88 & .53 \\
Closure of open range & 81 & 78 & .96 \\
Recreation access & 74 & 73 & .64 \\
Dogs & 64 & 62 & .46 \\
Wild predators & 57 & 52 & .11 \\
Tn & 57 & 46 & \\
\hline
\end{tabular}

n varies slightly by question.

side the scope of this study, for almost all the ranches, it was a male respondent who described himself as the "main decisionmaker." Most participated in land conservation through the Williamson Act, had goals of improving livestock production and wildlife habitat, and found the same information sources useful, preferring most to get information from other ranchers. Using volunteer labor and the work of friends and relatives was common practice; peer relationships were relied on to resolve conflicts, rather than involving outside authority. Ranchers share a love of the land and the camaraderie of the ranching community, and their motivations reflect a long history and identification as stock-raising pastoralists. Almost all found the lifestyle, for themselves and their fam-

Table 7. Desired outcomes of ranch sale, Tehama and Alameda-Contra Costa Counties, Calif. 1994.

\begin{tabular}{|c|c|c|c|}
\hline Would be a good outcome of ranch sale: & $\begin{array}{l}\text { Tehama } \\
\text { Ranchers } \\
(\mathrm{n}=132)^{1}\end{array}$ & $\begin{array}{c}\text { Alameda/Contra } \\
\text { Costa Ranchers } \\
\qquad(n=113)\end{array}$ & $\mathrm{P}\left(\mathrm{X}^{2}\right)$ \\
\hline & \multicolumn{2}{|c|}{ 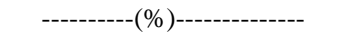 } & \\
\hline Stays a ranch used for livestock grazing & 76 & 48 & .00 \\
\hline The above makes no difference to me & 20 & 36 & .00 \\
\hline Is developed for housing & 6 & 23 & .00 \\
\hline The above makes no difference to me & 16 & 26 & .00 \\
\hline The ranch stays private & 81 & 55 & .00 \\
\hline The above makes no difference to me & 17 & 38 & .00 \\
\hline Goes to a public agency & 2 & 3 & .73 \\
\hline The above makes no difference to me & 11 & 25 & .00 \\
\hline Goes to a non-profit & 4 & 13 & .00 \\
\hline The above makes no difference to me & 16 & 31 & .00 \\
\hline Is designated open space & 16 & 22 & .32 \\
\hline The above makes no difference to me & 21 & 19 & .62 \\
\hline Has no livestock grazing & 3 & 3 & .87 \\
\hline The above makes no difference to me & 16 & 23 & .20 \\
\hline Hunting takes place on it & 19 & 14 & .28 \\
\hline The above makes no difference to me & 38 & 38 & .95 \\
\hline
\end{tabular}

ranchers intend to sell their land, and are not as concerned with the day to day ranching operation. Several answers indicate this: they were less likely to care about the fate of the ranch land if sold, the friendship of their neighbors, the interest of their children in ranching, and water quality regulations, and they were much more threatened by land use regulations that affect ability to sell. Local land use planning was rated a serious or extreme threat to ranching by almost $80 \%$ of ACC respondents, nearly $30 \%$ more than in Tehama. Ranchers in ACC clearly have strong interest in maintaining the opportunity to develop land.

Ranchers in Alameda and Contra Costa Counties do seem to partially fit the "impermanence syndrome." For the majority of ACC ranchers, selling the ranch for development either was not bad or they simply did not care. Half of ACC respondents, earning a quarter or less of their income from ranching, depended on outside income sources. Tehama ranchers earned a greater portion of their income from the ranch, and indicated dependence on ranching as a job. But the survey did not reveal the expected decrease in management activity in ACC compared with Tehama County, or major differences in goals. Important ACC management goals included improving livestock quality, increasing forage and livestock production, and improving or maintaining soil stability near streams. In fact, more than two-thirds of ACC ranchers made water improvements on their ranches during a 5 year drought that included the year of this study, more so than Tehama ranchers, though water improvements are not as needed in Tehama where range is used less often in summer. Burning, fencing, and fertilization were more common range improvements in Tehama. Water improvements typical in ACC could be seen as stop-gap measures to protect the herd, an asset with no alternative value, rather than an investment in the productivity of land worth more as real estate. However, seeding was done with the same frequency in both study areas. This topic remains an area for future research.

Several interviewed ACC ranchers indicated that they want to continue ranching, but plan to use ACC land sale profits to buy a larger ranch in a rural community welcoming of ranching, and with lower land prices. Two interviewed ACC ranchers were buying ranches in Tehama County.

Moving elsewhere to start anew can be difficult. All surveyed ACC respondents 
had owned their land for at least 10 years, with a mean of over 60 years, a significantly longer period of time than Tehama ranchers. An ACC ranch real estate specialist indicated that this lack of movement out of ranching and no recruitment of new ranchers was due to several factors:

1. Within areas zoned for development, it can still take years to sell grazing land because a myriad of interest groups impose conditions on the sale.

2. Ranches located outside development boundaries and zoned for agriculture, recreation, or open space, are still close to high value real estate within the designated urban boundary. The possibility of zoning changes inflates ranch prices. This may also lead ranchers to have unrealistic land price expectations, higher than the market will pay.

3 . The very factors that motivate ranchers to leave ACC, such as tight restrictions, increasing frustrations in conducting daily operations, and anti-grazing sentiments, drive away prospective ranchers.

\section{Land Use Planning and Conservation Incentives}

Ranchers not only obtain social fulfillment and livelihood from their land, they also see it as an insurance policy and retirement fund (Daniels 1991, Gobster and Dickhut 1988). A decrease in land value or an inability to sell some or all of their property undermines this security. In the more urbanized setting with higher land prices and more conflicts, ranchers were even less inclined to favor land use control.

Compensatory incentives such as landowner-negotiated conservation easements that protect ranching as a land use are voluntary and even offer a source of funds. Yet less than 5 percent of ranchers had land in conservation easements. The main land conservation policy tool widely accepted by ranchers in both study sites is the tax relief of the Williamson Act. Since ranchers can pull out of the program after a 10 year period, they feel they are not relinquishing future options.

\section{Policy Approaches}

Retaining ranching, whether for open space, historic preservation, or food and fiber production, takes policies and actions that work in concert, if at different scales. This research offers some insight to approaches needed at 3 different scales: national/international, landscape/commu- nity, and local/neighbor to neighbor. At the national or international level, policies that improve prices to rangeland producers, consider the fate of ranch land under tax regimes, and encourage agencies to use an ecosystem management approach that considers the surrounding landscape could be considered.

At the landscape level, an important goal is to manage the pattern and direction of growth to maintain rural landscape character and a ranching community critical mass to support markets and facilities (Huntsinger and Hopkinson 1996, Hart 1991b). Conservation easements and land use planning are common landscape level approaches, but a stronger commitment to urban planning would be of great benefit. About a third of the ranchers in this study used some public lands, and the need for continued access to public grazing lands makes relations with public land agencies crucial. Collaborative management programs and mutual consultation and trust with agencies may be critical to establishing a sustainable ranching landscape.

At the local or community level, where ranch and suburban or urban lands meet, policy and regulatory arrangements should minimize and control unwanted impacts. These include policies to control "nuisances," "right to farm" ordinances, and regulation of water and air quality. Just as landscape level policies give local conflicts their character and magnitude, the effectiveness and equity of policy for mitigating unwanted impacts ultimately shapes very local, person to person, landowner to landowner interactions. Local level problems with urban neighbors sometimes arise out of misunderstanding, lack of knowledge and information, and plain disagreement about land management. Emphasis on mutual education, collaborative alliances, and other "ground up" paths to mitigating conflicts are needed. In Marin County, California, as an example, environmentalists supported county aid for needed water quality improvements on local dairy ranches, and this helped build a collaborative land conservation strategy for the county (Huntsinger and Hopkinson 1996). When feasible, development of local markets for ranch products may help (Hart 1991b).

This study supports earlier research that found lifestyle a major motivation for ranching despite urbanization's effects, and despite the generally dismal profits to livestock producers in recent decades. Ranchers have strong environmental values, but dislike outside control, including environmental regulations. As landscapes become more urban, increasing difficulties with ranching combine with growing expectations of lucrative land sales, and the ranching community becomes more hostile to land use control. Escalating land prices make the costs of incentive-based land conservation programs rise, and attrition of the ranching community threatens the economic and social viability of ranching. Ideally, rangeland conservation programs should begin early, so that a viable ranching community, and its attendant infrastructure, can be maintained.

For some relationships, a "tipping point," or threshold model may be a better fit than a linear or curvilinear correlation. Future research might examine the possibility that the relationship between urbanization and the rancher's inclination to continue ranching might be best described with a threshold model. Ranchers persist and adapt for a time as rural lands succumb to urban outgrowth and subdivision. But consciously or otherwise, ranchers recognize the importance of the social and environmental landscape connections that enable ranching. There comes a point when the landscape begins to be widely recognized as "urban" in character, rather than rural. At this threshold, ranchers shift from thinking about ranching as a long term part of the landscape to a phenomenon moribund in their locale. Committed to ranching as a lifeway, they look elsewhere to continue it, less concerned with the future of the functionally compromised land they now occupy, and more concerned for the short haul with maintaining their opportunity to liquidate.

\section{Literature Cited}

ACPD [Alameda County Planning Department]. 1994. East county area plan: a portion of the Alameda County general plan. Hayward, Calif.

Alterman, R. 1997. The challenge of farmland preservation: lessons from a six-nation comparison. J. of the Amer. Planning Assoc. 63(2):220-243.

Bartlett, E. T., R. G. Taylor, J. R. McKean, and J.G. Hof. 1989. Motivation of Colorado ranchers with federal grazing allotments. J. Range Manage. 42(6):454-457.

Berry, D. and T. Plaut. 1978. Retaining agricultural activities under urban pressure: a review of land use conflicts and policies. Policy Sci. 9(2): 153-178.

Bolsinger, C. L. 1988. The hardwoods of California's timberlands, woodlands, and savannas. USDA, Forest Serv. Resour. Bull. PNW 148, Portland, Oreg.

California Dept. of Finance. 1996. California statistical abstract. State of Calif, Sacramento, Calif. 
Conklin, H. E. and W.G. Lesher. 1977. Farm-value assessment as a means for reducing premature and excessive agricultural disinvestment in urban fringes. Amer. J. Agr. Econ. 59(4):755-759.

CCCCDD [Contra Costa County Community Development Department]. 1991. Contra Costa county general plan 1990 - 2005. Martinez, Calif.

Contra Costa County Department of Agriculture. 1993. County Agricultural Commissioner's Report.

Daniels, T. L. 1991. The purchase of development rights: preserving agricultural land and open space. J. of the Amer. Planning Assoc. 57(4):421-431.

Dillman, D. A. 1978. Mail and telephone surveys: the total design method. Wiley and Sons, New York, N.Y.

Ellickson, R. C. 1991. Order without law. Harvard Univ. Press, Cambridge, Mass.

Ewing, R.A., N. Tosta, R. Tuazon, L. Huntsinger, R. Marose, K. Nielson, R. Motroni, and S. Turan. 1988. California's forests and rangelands: growing conflict over changing uses. Calif. Dept. of For. and Fire Protection. Anchor Press, Sacramento, Calif.

FMMP [Farmland Mapping and Monitoring Program]. 1996. Farmland conversion report 1992 to 1994. Calif. Dept. of Cons., Sacramento, Calif.

Forero, L., L. Huntsinger, and W. J. Clawson. 1992. Land use change in three San Francisco Bay Area counties: implications for ranching at the urban fringe. J. Soil and Water Cons. 47(6):475-480.

Fortmann, L.P. and L. Huntsinger. 1989. The effects of nonmetropolitan population growth on resource management. Soc. and Nat. Res. 2(1):9-22.

Furuseth, O. and J. Pierce. 1982. Agricultural land in an urban society. Assoc. Amer. Geog. Monog., Washington, D.C.

Gale, D.E. 1992. Eight state-sponsored growth management programs: a comparative analysis. J. Amer. Planning Assoc. 58(4):425-39.

Gobster and Dickhut, 1988. Factors influencing landowner acceptance of open space preservation methods. Soc. and Nat. Res. 1(3):351-364.

Grigsby, T. L. 1976. Buckaroo ranchers: sociocultural factors related to economic performance among range livestock operators of southeastern Oregon. Ph.D. Diss. Univ. of Ore, Eugene, Ore.

Grigsby, T. L. 1980. Today's riders of the purple sage: symbols, values, and the cowboy myth. Rangelands 2(3):93-96.

Hargrave, T. 1993. The impact of a federal grazing fee increase on land use in El Dorado County, California. M.S. thesis. Univ. of Calif., Berkeley, Calif.

Hart, J. F. 1976. Urban encroachment on rural areas. Geog. Rev. 66(1):1-17.

Hart, J. F. 1991a. The perimetropolitan bow wave. Geog. Rev. 81(1): 35-51.

Hart, J. 1991b. Farming on the edge : saving family farms in Marin County, California. Univ. of Calif. Press, Berkeley, Calif.
Heimlich, R. E. and W. D. Anderson. 1987. Dynamics of land use change in urbanizing areas: experience in the economic research service, p. 135-154. In: William Lockeretz (ed.), Sustaining agriculture near cities. Soil and Water Cons. Serv., Washington, D.C.

Holzman, B.A. 1993. Vegetation change in California's blue oak (Quercus Douglasii) woodlands 1932-1992. Ph.D. Diss, Univ. of Calif., Berkeley, Calif.

Huntsinger, L., and P. Hopkinson. 1996. Viewpoint: Sustaining rangeland landscapes: a social and ecological process. J. Range Manage. 49(2):167-173.

Huntsinger, L., L. Buttolph, and $P$. Hopkinson. 1997. Ownership and management changes on California hardwood rangelands: 1985 to 1992. J. Range Manage. 50(4): 423-430.

Jacobs, L. R. 1991. Waste of the West: public lands ranching. Author, Tucson, Ariz.

Johnson, S. G. 1998. Oaks at the edge: land use change in the woodlands of the central Sierra Nevada, California. Ph.D. Diss., Univ. of Calif., Berkeley, Calif.

Johnston, T. R. and C. Bryant. 1987. Agricultural adaptation: the prospects for sustaining agriculture near cities, p. 9-21. In: William Lockeretz (ed.), Sustaining agriculture near cities. Soil and Water Cons. Serv., Washington, D.C.

Kaiser, E. J. and S. F. Weiss. 1970. Public policy and the residential development process. J. of the Amer. Inst. of Planners. 36(1):30-37.

Landis, J. D., T. Bradshaw, T. P. Hall., M. Teitz, E. Eagan, A. Pamuk, Q. Sheng, and D. Simpson. 1993. How shall we grow? Alternative futures for the greater San Francisco Bay Region. California Policy Sem. Res. Rep. Univ. of Calif., Berkeley, Calif.

Lisansky, J. and G. Clark. 1987. Farmer-nonfarmer conflicts in the urban fringe: will right-to-farm help? p. 219-230. In: William Lockeretz (ed.), Sustaining agriculture near cities. Soil and Water Cons. Serv., Washington, D.C.

Martin, W. E., and G. L. Jefferies. 1966. Relating ranch prices and grazing permit values to ranch productivity. Amer. J. of Agr. Econ. 48(2):233-242.

McClaran, M. P., J. Romm, and J. W. Bartolome. 1985. Differential farmland assessment and land use planning relationships in Tulare County, California. J. of Soil and Water Cons. 40(2):252-255.

Platt, R. H. 1991. Land use control: geography, law, and public policy. Prentice Hall, Englewood Cliffs, N.J.

Raymond, L. 1997. Viewpoint: Are grazing rights on public lands a form of private property? J. Range Manage. 50(4):431-438.

Roe, E., Huntsinger, L., and Labnow, K. 1998. High reliability pastoralism. J. Arid Environ. 39(1):39-55

Sandford, S. 1983. Management of pastoral development in the Third World. Wiley, New York, N.Y.
Smethurst, D. P. 1997. Transforming the high country: absentee ownership and environmental change in the central Sierra Nevada. PhD Diss. Univ. of Calif., Berkeley, Calif.

Smith, A. and W.E. Martin. 1972. Socioeconomic behavior of cattle ranchers, with implications for rural community development in the West. Amer. J. Agr. Econ. 54(2): 217-225.

Spicer, C.C. 1972. Calculation of power sums of deviations about the mean. Appl. Stat. 21(2):226-227.

Starrs, P. F. 1998. Let the cowboy ride: cattle ranching in the American West. Johns Hopkins Univ. Press, Baltimore, Md.

Tehama County Department of Agriculture. 1993. County Agricultural Commissioner's Report.

Tehama County Planning Department. 1990. Tehama County General Plan. Red Bluff, Calif.

U.S. Department of Commerce, Bureau of the Census. 1992. California Census of Agriculture. U.S. Govt. Printing Office, Washington, D.C.

U.S. Department of Commerce. Bureau of the Census. 1994. County and city data book. U.S. Govt. Printing Office, Washington, D.C.

Wright, J. B. 1993a. Conservation easements - an analysis of donated development rights. J. Amer. Planning Assoc. 59(4): 487-493.

Wright, J.B. 1993b. Rocky Mountain divide: selling and saving the West. Univ. of Texas Press, Austin, Tex.

Wright, J.B. 1994. Designing and applying conservation easements. J. Amer. Planning Assoc. 60(3): 380-388.

Wuerthner, G. 1990. The price is wrong. Sierra 75(5): 38-43. 